\title{
The Recording Acts and Titles by Adverse Possession and Prescription
}

$\mathrm{T}$

HE recording acts are distinctly an American contribution. According to a learned writer, ${ }^{1}$ their origin can be traced to a statute of the Massachusetts Bay Colony enacted in the year 1640. Recording as an incident to the conveyance of real estate has long since become so universal in this country as to have given rise to a somewhat common fallacy among laymen that a deed, though delivered, is without legal effect unless recorded. ${ }^{2}$

It is hardly surprising that so simple a statutory requirement as that of the usual recording statute, ${ }^{3}$ superimposed upon an existing complexity of conveyancing and property law should fail to afford even an approximate guaranty to a purchaser that a title is actually what the public records make it appear to be. Various risks incurred in the purchase of a perfect "record" title have frequently been pointed out, both by advocates of the so-called "Torrens" system of registration and others. ${ }^{4}$ Among the more important of these may be mentioned the possibility of the invalidity or ineffectiveness of any of the conveyances in the chain of title due to the incapacity of the grantor, forgery (including cases where the grantor is another person having the same name as the actual owner), or want of delivery, ${ }^{5}$ and the possibility that the title may have been extinguished

${ }_{1}^{1}$ Joseph H. Beale, 19 Green Bag, 335.

2 See Kenney v. Parks (1902) 137 Cal. 527, 70 Pac. 556; Stone v. Daily (1919) 181 Cal. 571, 577, 185 Pac. 665; Hotaling v. Hotaling (1924) 193 Cal. 368, 382-4, 224 Pac. 455. These cases make the distinction that although a deed delivered to the grantee conditionally, e. g., with the understanding that it shall be effective only if the grantee survives the grantor, takes effect immediately upon such delivery, discharged of the condition (Cal. Civ. Code, $\S 1056$ ), nevertheless if at the time of the conditional delivery to the grantee both parties mistakenly believe that the deed will have no legal effect until recorded and intend that it shall not be recorded until the happening of the condition, it will be entirely inoperative (in Stone v. Daily, even though the condition-the survival of the grantee-actually took place).

3 e. g. Cal. Civ. Code $\$ \$ 1213,1214$, which in substance provide, first, that a properly recorded conveyance is constructive notice of its contents to subsequent purchasers and mortgagees; and second, that an unrecorded conveyance is void as against a subsequent bona fide purchaser for value whose conveyance is first duly recorded. Many states omit the provision that the bona fide purchaser's deed be first recorded. Frequently, the statute does not in terms provide for constructive notice through recordation but this is held to follow, by judicial construction. See 2 Pomeroy, Equity Jurisprudence, $\S 649$; Ralph W. Aigler, The Operation of the Recording Acts, 22 Michigan Law Review, 405.

${ }^{4}$ See, e. g., J. R. Rood, 12 Michigan Law Review, 379.

5 It is noteworthy, however, that at least one state has provided by statute that a bona fide purchaser shall be entitled to rely upon recordation as conclusive evidence of the delivery of a deed. General Laws of Massachusetts, 1921, c. $183, \& 5$. 
by adverse possession or have become subjected to an easement by prescription.

By securing an adequate policy of title insurance the purchaser may often eliminate, or more properly speaking, secure protection in the form of insurance against, several of the risks previously mentioned. ${ }^{6}$ It seems to be the common practice, however, for policies of title insurance to make a specific exception of adverse possession from the risks covered. Most laymen and many lawyers, no doubt, feel that sufficient precaution against such a risk is taken by an actual inspection of the property in order to ascertain whether or not anyone claiming adversely to the seller is in possession, and conclude that they may rest secure in the absence of any such occupant.

The courts have uniformly held, however, in the relatively few cases in which the question has been presented, that a title by adverse possession when once acquired is paramount to that of a subsequent bona fide purchaser of the record title even though the adverse possessor is not in possession at the time of purchase, and the purchaser, therefore, has not the slightest notice as to the existence of any such adverse interest. " These decisions are based upon the fact that the recording statutes are by their own terms inapplicable to titles acquired by adverse possession. They only purport to invalidate conveyances and other instruments which are not recorded before the bona fide purchaser's rights accrue. A title by adverse possession is acquired through the operation of the statute of limitations and not by any instrument which should have been placed of record. Although probably contrary to the spirit of the recording acts, the logic of these decisions would seem to be unanswerable.

\section{Adverse Possession Under An Unrecorded Deed}

It remained for the Supreme Court of Alabama in 1912 in the case of Winters v. Powell, ${ }^{8}$ to make what some may regard as a

${ }^{6}$ All title insurance policies do not restrict the risks insured against to defects in the record title. See Title Insurance \& Trust Company v. City of Los Angeles (1923) 61 Cal. App. 232, 214 Pac. 667, for a reference to the two different forms of policy. Cf. Bothin v. California Title Insurance \& Trust Company (1908) $153 \mathrm{Cal}$. 718, 722, 96 Pac. 500, 502: "Necessarily the record title is all that a title insurance company can safely or judiciously insure".

7 Faloon v. Simshauser (1889) 130 Ill. 649, 22 N. E. 835; Ridgeway v. Hofliday (1875) 59 Mo. 444; Schall v. Williams Valley R. Co. (1860) $35 \mathrm{~Pa}$. 191; MacGregor v. Thompson (1894) 7 Tex. Civ. App. 32, 26 S. W. 649; East Texas Land etc. Co. v. Shelby (1897) 17 Tex. Civ. App. 685, 41 S. W. 542.

8180 Ala. 425,61 So. 96 ; s. c. on a subsequent appeal sub nomr. Nolen v. Powell (1913) 64 So. 566. 
novel and perhaps unwarranted application of the doctrine of these cases. The grantee in an unrecorded deed from the actual owner had been in possession of the land for more than the statutory period of limitations. After his death, his wife secured and recorded a deed from her husband's grantor to herself and conveyed to a bona fide purchaser. The children, who were devisees under the husband's will, subsequently claimed the property. In deciding in their favor the court held that the husband had acquired title by adverse possession and that only such title as he had obtained through the unrecorded deed and not the title by adverse possession was invalidated by his failure to place the deed on record. ${ }^{2}$ This decision, if correct, would seem to impose a further limitation upon the operation of the recording acts. The failure to record a deed will be immaterial if sufficient time elapses between the execution of the unrecorded deed and the subsequent one to the bona fide purchaser to permit the first grantee to acquire an independent title by adverse possession.

Winters v. Powell has not escaped criticism. In disagreeing with the decision an able writer contends that the possession of one holding a valid deed from the true owner cannot be adverse to the

9 The actual facts of Winters v. Powell were somewhat more complicated than would appear from the above statement. In 1868 one Pinson was the owner and in possession of the land in question. In that year he sold it to George Powell, whom he put in possession without giving a deed. In 1871, however, he delivered to Powell the deed which he, Pinson, had previously received from his own grantor, endorsing upon it a signed and witnessed statement of transfer of the land to Powell. Powell continued in possession for more than the statutory period of limitations but never recorded this deed or the endorsement thereon. In 1879 Powell died, devising all his property to his widow, Fanny Powell, for life, remainder to his children. Mrs. Powell continued in possession of the land and in 1888 procured a deed from Pinson (her husband's grantor) to herself in fee. On the strength of this deed, she subsequently sold the land to one Batson, who in turn sold to the defendant's testatrix. It seems not to have been disputed that the latter, if not Batson, was a bona fide purchaser for value without notice of the interest of the Powell children, the remaindermen under the will of George Powell. The court held that conceding that Pinson's endorsement on the prior deed amounted to a conveyance to George Powell within the meaning of the recording acts, nevertheless Powell was in no worse position by reason of having an unrecorded deed from Pinson than he would have been had he secured no deed at all, and that he had accordingly acquired title by adverse possession. This title passed to the remaindermen and was not extinguished by the subsequent intervention of a bona fide purchaser. Two justices disagreed with the decision of the majority of the court. Their dissenting opinion does not make it entirely clear whether they were of the opinion that it was not legally possible for Powell to acquire title by adverse possession when he had obtained the deed from the actual owner, or whether they felt that the principle of the recording acts demanded the construction of some sort of estoppel against Powell and his successors to prevent their reliance upon such adverse possession against a bona fide purchaser. 
latter because not wrongful.10 It is true that the usual adverse possession is a wrongful one but there is no legal requirement that it be so. The possession of any one claiming to be the owner against the whole world, on whatever ground, rightful or wrongful, would seem to be adverse in the legal sense, even as to the possessor's grantor against whom he may have no consciousness of hostility. Numerous cases hold that the possession of a donee under a paral gift is adverse to the donor. ${ }^{21}$ The donee's possession is certainly not wrongful. $\mathrm{He}$ is not liable as a trespasser, and has at least the status of a tenant at will. His possession, nevertheless, is almost without exception recognized as sufficient to confer upon him after the lapse of the statutory period of limitations a valid title as against the donor. Though there is seldom any necessity for so characterizing it, the possession of the holder of a valid title would seem to be the very acme of adverse possession. The decision in Winters $v$. Powell is not in accord with the spirit of the recording acts but criticism of it on the ground that the possession of a grantee cannot be adverse because not wrongful would seem to be unwarranted.

It may be argued that the Alabama court might have reached a contrary decision on the ground that as against the bona fide purchaser-second grantee the statute of limitations did not commence to run in favor of the adverse possessor-first grantee until the

${ }_{10}$ Tiffany, Real Property (2d ed.) p. 1987: "Having obtained a decd from the rightful owner, his possession ceases to be wrongful, and the statute runs only in favor of a wrongful possession." See also 26 Harvard Law Review, 762: "After the delivery of the unrecorded deed, therefore, the grantee's possession could not be adverse, and rights under the unrecorded deed should be inferior to those of the bona fide purchaser of the rccord title."

11 Lee v. Thompson (1892) 99 Ala. 95, 11 So. 672; Bakersfield Town Hall Association v. Chester (1880) 55 Cal. 98; Baldwin v. Temple (1894) $101 \mathrm{Cal} .396,35$ Pac. 1008; Thomson v. Thomson (1892) 93 Ky. 435; Sumner v. Stevens (1843) 6 Met. 337; Schafer v. Hauser (1897) 111 Micl. 622, 70 N. W. 136; 66 Am. St. Rep. 403; 35 L. R. A. 835; Davis v. Bowmar (1878) 55 Miss. 671; Rannels v. Rannels (1873) 52 Mo. 108; Campbell v. Braden (1880) $96 \mathrm{~Pa}$. 388; Pope v. Henry (1852) 24 Vt. 560. For additional cascs, sce notc 35 L. R. A. 835.

The point which the writers previously referred to seek to make (sce, supra, n. 10) may possibly be that the posscssion of one holding a deed from the owner should not be considered adverse because not actionable. The cascs holding the possession of a donee under a parol grant to be adverse are perhaps distinguishable on this ground. In the analogous situation involving an oral grant of an easement, however, the user of a donee or grantee is not actionable so long as the license resulting from the oral grant remains unrevoked, but is nevertheless adverse. Frederick v. Dickey (1891) 91 Cal. 358, 360, 27 Pac. 742; Alper v. Tormey (1907) 7 Cal. App. 8, 13, 93 Pac. 402; Lechman v. Mills (1907) 46 Wash. 624, 91 Pac. 11. For additional cases see notes 13 L. R. A. (N. S.) 991, and 13 Ann. Cas. 925; and 22 Am. \& Eng. Ency. of Law (2d ed.) 1198. 
execution of the deed to the bona fide purchaser. Such a conclusion, however, would seem difficult to sustain on principle. It is almost axiomatic that where land is held by an adverse possessor a conveyance by a dispossessed owner does not affect the operation of the statute of limitations. ${ }^{12}$ If the statute has already run against the grantor, the grantee is equally barred from recovering possession. If the statutory period has only partially elapsed, the statute continues to run against the grantee as from the original date. In other words, the grantee steps into the shoes of his grantor. Now, what different result is caused by the grantee being also a bona fide purchaser for value claiming under a deed subsequent in date to the unrecorded deed of the adverse possessor? In one respect, to be sure, such a grantee does not step into the shoes of his grantor. He may deny, as his grantor never could, the validity of the prior unrecorded deed. But if the adverse possessor-first grantee relies upon his possession rather than upon his unrecorded deed, the situation becomes identical with the one previously considered, where the grantee stands in the same position as his grantor.

\section{Easements By Prescription}

It would seem reasonable to expect that the effect of the recording acts upon easements acquired by prescription would be the same as upon titles by adverse possession. If a bona fide purchaser is not protected against a title by adverse possession of which he has no notice, either actual or constructive, why should he be allowed to take free of an easement gained by adverse use? The reason for excluding titles by adverse possession from the operation of the recording statutes, namely that the latter affect only conveyances, which are capable of being placed of record, would seem to apply equally to easements by prescription. In the actual decisions, however, there is neither the same unanimity of opinion nor the clear recognition of principles found in the cases concerning adverse possession. In one state the question has been squarely decided in favor of the holder of the easement, but without any enlightenment as to the precise basis of the decision..$^{13}$ The Massachusetts court,

12 Le Roy v. Rogers (1866) 30 Cal. 230, 235.

13 Shaughnessey v. Leary (1894) 162 Mass. 108, 112, 38 N. E. 197. The court also refers to the case of Johnson v. Knapp, 146 Mass. $70,73,15 \mathrm{~N}$. E. 134. There it simply seems to have been assumed that if the evidence had been sufficient to establish the existence of an easement by prescription (which it was not) such an easement could have been relied upon even against a subsequent bona fide purchaser of the record title. 
speaking through Mr. Justice Holmes, merely says: "The registry laws do not extinguish easements by prescription in favor of purchasers without notice", citing Massachusetts Public Statutes, chapter 120 , section 4 . Inasmuch as this statute simply provides that conveyances of various specified interests in real property are not valid against bona fide purchasers unless recorded, it may not be unreasonable to presume that the basis of the court's decision was the same as that of the cases previously referred to which reach a similar conclusion as to titles by adverse possession.

On the other hand it has been held in one jurisdiction, ${ }^{14}$ and apparently been taken for granted in several others, ${ }^{15}$ that a bona fide purchaser would take free of an easement created by prescription. In these latter cases the circumstances were such as to give the purchaser notice of the easement, and the courts held that because he had such notice he took subject to it. The implication was that if there had been no notice the easement would have been extinguished. Such a holding is in accord with the spirit of the recording acts, but can it be sustained on principle? A possible justification is the fiction of the "lost grant", generally given as the basis for the recognition of prescriptive rights. ${ }^{13}$ Following this

14 Schwartz v. Atlantic Building Co. (1913) 41 App. D. C. 108, 111: "It is contended that, inasmuch as the wall had been constructed more than twenty years prior to plantiff's acquiring the property, it will be presumed, in the absence of evidence to the contrary, that an easement by prescription was acquired with the knowledge of the then owner, plaintiff's grantor, which would be binding upon plaintiff as his successor in interest. Plaintiff testified that he had no knowledge of the encroachments until he dug down and found them. A concealed easement of this character upon land, in the absence of any record or other means of putting the purchaser upon notice, will not pass with a conveyance of the land. Defendant, therefore, had no easement to the extent of these encroachments which he could enforce against the plaintiff."

15 Schmidt v. Brown (1907) 226 I11. 590, 80 N. E. 1071; Sparks y. Rogers (1906) $29 \mathrm{Ky}$. Law Rep. 1170, $97 \mathrm{~S}$. W. 11; St. Cecelia Society v. Universal etc. Co. (1921) 213 Mich. 569, 182 N. W. 161; Van De Vanter v. Flaherty (1905) 37 Wash. 218, 79 Pac. 794.

16 The earliest statutes of limitations were in terms applicable only to actions for the recovery of the possession of land. The acquisition of socalled "incorporeal" rights, such as easements, through adverse use rested upon the independent doctrine of prescription, i. e. usage "from a time whereof the memory of man ran not to the contrary", in legal phraseology. Such immemorial usage gave rise to the presumption of the lawful origin of the right in question. Through a judicial extension of one of the early statutes of limitations ( 3 Edw. I, c. 39 (1275)) the date therein fixed (1189) as the earliest at whicls the plaintiff's seisin could be relied upon in actions to recover the possession of land was held by analogy to fix the limits of legal memory back of which it was not necessary to go to establish immemorial usage in the case of prescriptive rights. When a later statute ( 32 Henry VIII, c. 2 (1540)) adopted for the first time the modern method of fixing as the basis for the limitations of actions a period of time elapsing between the accrual of the cause of action and the commencement of suit, the courts 
fiction to its logical conclusion leads to the decision that the grant which is presumed to have been made and lost should have been placed of record to be effective against bona fide purchasers. Unlike the adverse possessor, whose claims do not rest upon the supposition of any grant, ${ }^{17}$ the prescriptive user can thus be brought within the terms of the recording statutes. He is claiming through a lost and unrecorded conveyance and therefore cannot prevail as against a bona fide purchaser.

There is, furthermore, some basis for thus carrying out to its logical conclusions the lost grant theory, though it be an admitted fiction. In a number of cases the courts have held that where it appeared that a valid grant of the easement never could have been made, no right was acquired by adverse user. ${ }^{18}$

did not, according to the generally accepted opinion, hold that the limit of legal memory was likewise shortened to the sixty year period provided for by the new statute. See 2 Rolle's Abr., tit. Prescription, 269; Gale on Easements (10th ed.) 189-191; Coolidge v. Learned (1829) 8 Pick. 503; Wallace v. Fletcher (1855) $30 \mathrm{~N}$. H. 434. The practice eventually arose, however, of recognizing a presumption of a lost grant where the adverse use had continued for the period of the statute of limitations. Unlike the presumption of grant or other lawful means of origin upon which user from time immemorial necessarily rested, this later presumption was originally regarded as a rebuttable one. As it developed in the hands of the courts, in instructing juries and setting aside their verdicts, however, it fell but little short of a conclusive presumption or fixed rule of law, and evidence that no grant was ever made in fact was generally regarded as immaterial. Angus v. Daiton (1877) L. R. 3 Q. B. Div. 85, s. c. (1878) L. R. 4 Q. B. Div. 162, s. c. (1881) 6 App. Cas. 740. In 1832 in England the so-called "Prescription Act" (Stats. 2 and $3, \mathrm{Wm}$. IV, c. 71) brought the doctrine for the first time within the definite provisions of a statute. In this country although the period of use necessary to establish rights by prescription is still derived by analogy from the statutes of limitations, and the courts frequently refer to the presumption of a lost grant, no evidence to rebut the presumption is generally admitted. Coolidge v. Learned, supra; Wallace v. Fletcher, supra; Smith v. Hawkins (1895) $110 \mathrm{Cal}$. 122, 126, $42 \mathrm{Pac} .453$, 454: "One who claims a right by prescriptiou must use the water continuously, uninterruptedly, and adversely for a period of at least five years, after which time the law will conclusively presume an antecedent grant to him of his asserted right". The dictum in Thomas v. England (1886) 71 Cal. 456, 458, 12 Pac. 491, 492, that "prescription, as understood and interpreted in modern times, raises a legal presumption of title under a grant, but is not conclusive, and may be rebutted by other evidence", is not supported by the great weight of authority. See Tiffany, Real Property (2d ed.) p. 2030.

17 People v. Banning (1914) 167 Cal. 643, 649, 140 Pac. 587.

18 Woodworth $v$. Raymond (1883) 51 Conn. 70, holding no prescriptive right of way could be gained over land owned by Indians, who were incapable of making a legal grant. City of Quincy v. Jones (1875) $76 \mathrm{I11}$. 231, holding no right to lateral support for buildings could be gained by prescription, as against municipally owned land used as a public street, since the city could not have made such a grant. Inhabitants of Brookline v. Mackintosh (1882) 133 Mass. 215, holding one could not acquire a prescriptive right to pollute a public water supply, since there was nobody empowered under the law to grant such a right. Hume v. Rogue River Packing Co. (1907) 51 Ore. 237, 92 Pac. 1065, 31 L. R. A. (N. S.) 396, 131 Am. St. 
On the other hand, in a situation which is probably more analogous to the problem under discussion, the authorities are in conflict as to whether the logical consequences of the lost grant fiction should obtain. When a disability such as infancy or insanity on the part of the owner arises after the adverse use has commenced, a number of cases hold that the running of the statute of limitations is suspended during the continuance of such disability. ${ }^{10}$ No presumption of a grant from the owner's acquiesence is logically permissible, they reason, where he was legally incapable of taking any affirmative action. Practically, however, it would seem to be preferable that prescription, which is based on an analogy to the statutes of limitations, should be governed wherever possible by the provisions of the latter. Since such statutes in terms provide that supervening disabilities are to be disregarded in actions brought to recover possession, should the palpable fiction of lost grant be permitted to produce a contrary result in cases of prescription? This seems to be the attitude of the sounder decisions, which hold that the provisions of the statutes of limitations that only disabilities existing when the cause of action accrues are to be recognized, apply by analogy to cases of prescription. ${ }^{20}$ In these jurisdictions, it would seem reasonable to conclude, the courts would be unwilling to permit the lost grant fiction to make a difference between adverse possession and prescription in connection with the recording acts.

\section{EASEMENTS By IMPLication}

While not within the scope of the title of this article, easements created by implication ${ }^{21}$ raise a problem in connection with the recording acts very similar to those which have previously been referred to regarding adverse possession and prescription. Here, just as in the cases involving prescriptive easements, the courts frequently assume that an easement created by implication is enforceable against a subsequent purchaser of the servient tenement only because of the fact (which generally exists) that he had notice

Rep., holding that there could be no prescriptive right of an exclusive fishery in the waters of a navigable river, since the state was not authorized to make such a grant.

19 Thorpe v. Corwin (1844) 20 N. J. L. 311; Hodges v. Goodspeed (1898) 20 R. I. 537, 40 Atl. 373; Lamb v. Crosland (1851) 4 Rich. Law (S. C.) 536; Saunders v. Simpson (1896) 97 Tenn. 382, 37 S. W. 195.

20 Ballard v. Demmon (1892) 156 Mass. 449, 31 N. E. 635; Mebane v. Patrick (1853) 46 N. C. 23; Wallace v. Fletcher (1855) 30 N. H. 434; Scallon v. Manhattan Ry. Co. (1906) 185 N. Y. 359, 78 N. E. 284; Reimer v. Stuber (1853) 20 Pa. St. 458, 59 Am. Dec. 744 ; Tracy v. Atherton (1864) 36 Vt. 503.

21 This of course includes both easements of strict necessity and so-called "continuous and apparent" easements. 
of the easement at the time of his purchase. ${ }^{22}$ Occasionally there is a square decision in a situation where there was no such notice, holding that the purchaser takes free of the easement. ${ }^{23}$ The courts are not careful to point out, however, on what precise legal principle such decisions are based. The recording acts and the equitable doctrine regarding bona fide purchasers of the legal title are together probably responsible for the existence of a somewhat general notion that no right or interest in land whatsoever has any validity as against a "B. F. P." It would seem, however, that the terms of the recording statutes are almost as inapplicable to easements created by implication as to titles by adverse possession or easements by prescription. How can the penalties of the recording acts properly be applied to the grantee who has duly recorded his deed to the dominant tenement and the existence of whose appurtenant easement rests upon the rule of law that the deed is to be interpreted or construed with reference to the physical situation existing between the two tenements when owned by the grantor? Perhaps the most plausible argument which can be made on behalf of the bona fide purchaser is that the easement created by implication is, from the standpoint of the recording acts, equivalent to one arising by oral grant, which clearly would be invalid as against a bona fide purchaser of the servient tenement, taking without notice of such an easement. ${ }^{24}$ The equitable doctrine of notice as it exists independ-

22 Ingals v. Plamondon (1874) 75 Ill. 118; Muir v. Cox (1901) $110 \mathrm{Ky}$. 560,62 S. W. 723 ; Eliason v. Grove (1897) 85 Md. 215, 36 Atl. 844; Board of Supervisors v. Elliott (1914) 107 Miss. 841, 66 So. 203; Shepardson y. Perkins (1878) 58 N. H. 354; Higbee Fishing Club v. Atlantic City Electric Co. (1911) 78 N. J. Eq. 434, 79 Atl. 326; Anania v. Serenta (1923) 275 Pa. 474, 119 Atl. 554; Rollo v. Nelson (1908) 34 Utah 116, 96 Pac. 263, 26 I. R. A. (N. S.) 315 .

23 Mesmer v. Uharriet (1916) 174 Cal. 110, 116, 117; 162 Pac. 104, 107, 108: "A purchaser of land for value takes subject only to interests in the land of which he has actual notice or which appear of record. The rule applies as well to easements as to claims of a greater interest. . . On the facts found the court should have concluded that the Uharriets were purchasers for value without notice, actual or constructive, of an easement, and that they therefore took their land free from any such easement if it had ever existed." The court also held that the defendants did have notice that a prior partition decree, through which title to both plaintiff's and defendants' lands was deraigned, had left plaintiff's parcel entirely surrounded by the other parcels, so that it might have a way of necessity over any one of the several parcels adjacent; but that purchasing one of these parcels twenty years later, defendants were not "bound to examine the records affecting the various other parcels adjoining plaintiff's land, or those parcels themselves, in order to ascertain whether the plaintiff had an outlet over any of these", but "were entitled to rest upon the want of any record showing affirmatively that a right of way existed over the fifty acres, coupled with the physical conditions indicating that there was no such right."

${ }^{24}$ Jobling v. Tuttle (1907) $75 \mathrm{Kan}$. 351, 89 Pac. 699; Taylor v. Millard (1890) 118 N. Y. 244,23 N. E. 376. 
ently of the recording acts is scarcely material to the problem. As pointed out by a well considered English case, the creation of easements by implication rests upon established common law principles and will be enforced against subsequent purchasers irrespective of the equitable doctrine of notice. ${ }^{25}$

\section{Suggested Amendment of Recording Acts}

If a bona fide purchaser is to be protected against rights which have arisen by adverse possession or prescription-and it seems proper that he should be accorded such protection-the existing statutes with reference to recording should be supplemented by a provision bringing claims by adverse possession or prescription within their operation. The statute should specifically provide that rights or titles acquired by adverse possession or prescription shall not be valid against bona fide purchasers for value unless the adverse claimant in some manner puts his adverse clain on record so as to give constructive notice to such purchasers. This could of course be accomplished through the filing of a lis pendens in a quiet title suit against the holder of the record title. If it be regarded as unfair to the adverse claimant thus virtually to compel him to initiate litigation against the record title holder, provision might also be made for the recording of a simple statement of his adverse claim, including, of course, the name of the person in whom the title stands of record, so that the indexing essential for the giving of notice to subsequent purchasers may be made. ${ }^{28}$

A precedent for such an extension of the operation of the record-

25 Schwann v. Cotton (1916) 2 Ch. 459, 468: "It is then said that . . she is a purchaser for value without notice and cannot he affected by the right claimed by the plaintiff, and it is urged that for some years the existence of the pipe and watercourse ... was not visible at Malta [the servient tenement] . . I am not satisfied that this is any answer to the plaintiff's case which rests not on an implied covenant but on an implièd grant. A grantor must not derogate from his own grant. That is a common law doctrine and must be enforced irrespective of the equitable doctrine of notice."

${ }^{28}$ The objection will doubtless be made that only one who is cognizant of the fact that he is an adverse possessor will be likely to put his claim of record pursuant to the provisions of such a statute, and that a bona fide adverse possessor who believes himself to be the legal owner will thus be in a worse position than one who realizes the wrongful character of his possession. But is that fact a sufficient reason for protecting a bona fide adverse possessor at the expense of a bona fide purchaser of the record title, when the latter has no notice either actual or constructive, of the adverse claim? Ordinarily, of course, the adverse possessor will be in possession of the land and such possession will itself be sufficient to put a purchaser on notice of his claim. 
ing acts is to be found in Section 35 of the California Land Title Law, or "Torrens" Act, as it is frequently called, which provides:

"After land has been registered, no title thereto adverse or in derogation to the title of the registered owner shall be acquired by any length of possession." $2 \pi$

The effect of this enactment is apparently much more extended, in that it protects not only subsequent purchasers but also the owner himself from the consequences of adverse possession. ${ }^{28}$ It may not be improper to suggest a doubt as to the desirability of so sweeping an abrogation of the doctrine of adverse possession, when the "Torrens" system is in no more general use than at the present time in California. In a jurisdiction where all, or most, of the land has been brought under that system of registration, it may be arguable that there is little or no need for the acquisition or perfection of titles by adverse possession. It seems unfair and undesirable, however, to take away from particular possessory claimants the benefit of the doctrine of adverse possession simply because of the exceptional fact that the land which they occupy has been registered under the "Torrens" law. In this connection it should be noted that a number of jurisdictions which have adopted the "Torrens" system have done so without the inclusion of this provision doing away with the effect of adverse possession on registered land. ${ }^{29}$

School of Jurisprudence, $W . W$. Ferrier $J r$. University of California. 1915.

${ }^{27}$ Cal. Stats. 1915, p. 1939. Initiative act adopted by election Nov. 3,

28 The wording of the statute, however, offers to a court not in sympathy with its policy an opportunity to curtail its operation, contrary to the probable intentions of its framers. A distinction might be made between the operation of the statute of limitations as a bar to an action to recover possession and the additional effect (in California by reason of $\$ 1007$ of the Civil Code, but generally recognized independently of any express provision) affirmatively to vest title in the adverse possessor. In view of the doctrine that repeals by implication are not favored, would it be entirely unwarranted to hold that $\S 35$ of the Land Title Law simply renders ineffective the provision of $\S 1007$ with regard to the acquisition of title to registered land by adverse possession but does not prevent an adverse possessor from pleading Code of Civil Procedure $\S 318$ et seq. as a bar to the owner's action to recover possession?

${ }^{29}$ See Hogg, Registration of Title to Land Throughout the Empire, p. 85. 